\title{
ANALISIS HUKUM EKONOMI SYARIAH TERHADAP PEMBERIAN KREDIT KEPADA UMKM
}

\author{
Nurlina Taufik, Ashabul Kahpi \\ Universitas Islam Negeri Alauddin Makassar \\ Email: nurlinataufik11@gmail.com
}

\begin{abstract}
Abstrak
Kredit merupakan salah satu program dari bank yang mewujudkan pembangunan nasional bidang ekonomi, yang diharapkan sangat meningkatkan kesejahteraan rakyat. Kredit yang diberikan oleh bank kepada rakyat mengandung resiko sehingga dalam pemberian kredit harus memperhatikan asas-asas pengkreditan yang sehat berdasarkan prinsip kehati-hatian. Untuk itu sebelum memberikan kredit bank harus benar-benar melakukan penelitian yang seksama terhadap aspek khususnya dalam penelitian terhadap jaminan. Akan tetapi praktek penerapan pemberian kredit di berbagai perbankan yang ada belumlah sesuai dengan asas-asas hukum ekonom syariah dan juga tidak sesuai dengan UU Perbankan Syariah Pasal 5 No 20 Tahun 2008. Akan tetapi praktek penerapan pemberian kredit di berbagai perbankan yang ada belum berjalan sesuai dengan sistem dan asas-asas hukum ekonomi syariah, dan juga tidak sesuai pada tujuan dalam UU Perbankan Syariah. Misalnya pemberian kredit di bank konvensional tidak disertai dengan pengawasan penggunaan pinjaman beda halnya di sistem perbankan syariah memakai sistem pengawasan langsung pengguna kredit harus sesuai dengan tujuan kredit yang benar-benar dipakai untuk dunia usaha.
\end{abstract}

\section{Kata Kunci: Hukum Ekonomi Syariah, Kredit, Umkm}

\section{Abstract}

Credit is one of the programs of the bank that realizes the development of the national economy, which is expected to greatly improve the welfare of the people. Credit granted by the people's bank poses a great risk to the person who gives credit and must pay attention to the principles of sound credit based on the principle of prudence. For this reason, before providing credit, banks must really do careful research on aspects, especially in research on guarantees. However, the practice of applying credit in various existing banks is not in accordance with the legal principles of sharia economists and is also not in accordance with Article 5 of the Sharia Banking Law No. 20 of 2008. However, the practice of applying credit in various existing banks has not run in accordance with the system. and the principles of sharia economic law, and also not in accordance with the objectives of the Sharia Banking Law. For example, the provision of credit in conventional banks is not accompanied by supervision of the use of credit, unlike the Islamic banking system, which uses a direct supervision system for credit 
users, it must be in accordance with the purpose of credit that is actually used for the business world.

\section{Keyword: Credit, Sharia Economic Law, Umkm}

\section{A. PENDAHULUAN}

Islam adalah agama yang hadir sebagai penyempurnaan agama dengan sumber utamanya al-Qur'an dan sunnah rasulullah. Tidak hanya sekedar mengatur masalahmasalah yang berkaitan dengan ibadah tetapi juga mengatur tentang muamalah. Muamalah yang dalam arti luas merupakan aturan-aturan hukum Allah untuk mengatur manusia yang dalam kaitannya berurusan dengan duniawi dan pergaulan sosial. Sedangkan muamalah dalam arti sempit adalah aturan-aturan Allah yang wajib ditaati yang telah mengatur manusia yang satu dengan manusia yang lain dengan cara memperoleh dan mengembangkan harta benda. ${ }^{1}$

Islam menganggap penting urusan muamalah. Islam juga mengatur hubungan antara manusia dengan manusia lainnya. Islam adalah agama yang sempurna (komprehensif), kompleks dan dinamis yang mengatur aspek kehidupan manusia baik akidah, ibadah, akhlak maupun muamalah. ${ }^{2}$ Muamalah yaitu hukum hukum syara' yang berhubungan dengan urusan dunia untuk melanjutkan kehidupan, untuk mendapat alat keperluan jasmani dengan cara yang paling baik. ${ }^{3}$ Manusia diciptakan oleh sang pencipta dengan berbekal kekuatan yang luar biasa. Namun kekuatan itu tersembunyi dibalik dari manusia itu sendiri. ${ }^{4}$ Manusia merupakan makhluk sosial yang sangat membutuhkan bantuan dari orang lain. Manusia tidak dapat bertahan hidup tanpa meminta bantuan dari orang lain. Dalam hal ini pemenuhan kebutuhan hidup manusia juga harus meminta bantuan kepada orang lain. 5

Kegiatan perekonomian dalam pandangan Islam tidak hanya sekedar anjuran semata tetapi lebih dari itu merupakan sebuah tuntutan kehidupan yang memiliki dimensi ibadah. Ajaran Islam tidak menghendaki umatnya hidup dalam kekurangan dan keterbelakangan berbagai bidang. Khususnya keterbelakangan ekonomi karena kekayaan materi merupakan juga bagian yang penting dalam kehidupan kaum muslim. Melaui pertumbuhan ekonomi di Indonesia diharapkan dapat berkemban dari tahun ke tahun, melalui peran pemerintah dan pengusaha yang harus terus bersinergi dalam mengatur roda perekonomian. Adapun salah satu caranya ialah dengan mendorong dan mendukung unit usaha mikro kecil menengah (UMKM) yang mayoritas dimiliki oleh rakyat kecil

\footnotetext{
${ }^{1}$ Hendi Suhendi, Fikih Muamalah, (Jakarta: Rajawali Pers,2002). h.5

${ }^{2}$ Musyifikah Ilyas dan Sahruni Bahar, "Tinjauan Hukum Islam Terhadap Sistem Mappakatenni Galung Di Kel. Lalebata Kec. Panca Rijang Kab. Sidrap”, Jurnal Ilmiah Mahasiswa Hukum Keluarga Islam, 2 no. 1 (2020): h. 171.

${ }^{3}$ M. Thahir Maloko dan Rahmi Aulia Abshir, "Tinjauan Hukum Islam Terhadap Pengupahan Jasa Kerja Skripsi Secara Online”, Jurnal el-Iqtishady, 3 no. 1 (2021). h. 66.

${ }^{4}$ Mahmudah Mulia Muhammad, "Membentuk Sumber Daya Manusia Perbankan Syariah Melalui Manajemen Hati”, El-Iqtishadyl, No.2 (Desember 2019): h.33.

${ }^{5}$ Ashar Sinilele dan Naurah Aathifah Nursaidi, "Perlindungan Hukum Nasabah Dalam Transaksi Pinjaman Online (Fintech)", Jurnal el- Iqtishady, 3 no. 1 (2021): h. 99.
} 
yang membutuhkan dana atau uan untuk mendirikan dan membangun usaha mereka akan tetapi penyediaan dana atau uang merupakan momok masalahnya.

Maka kredit yang merupakan salah satu program dari bank diharapkan mampu mewujudkan pembangunan nasional dan mensejahterakan rakyat. Kredit yang diberikan oleh bank kepada rakyat mengandung resiko sehingga dalam pemberian kredit harus memperhatikan asas-asas pengkreditan yang sehat berdasarkan prinsip kehati-hatian. Untuk itu sebelum memberikan kredit bank harus benar-benar melakukan penilaian yang seksama terhadap aspek khususnya dalam penelitian terhadap jaminan. ${ }^{6}$ Pemberian kredit merupakan salah satu produk bagi vank dimana besaran kredit yang disalurkan bank dapat dijadikan sebagai pendapatan yang diperoleh dari pembayaran bunga kredit yang dapat dijadikan sebagai tambahan modal sedangkan bagi masyarakat kredit dapat menjadi sebuah tambahan modal usaha ataupun investasi. Pemberdayaan usaha kecil dan menengah merupakan langkah strategis dalam meningkatkan dan memperkuat dasar kehidupan perekonomian dari sebagian besar rakyat Indonesia, khususnya melalui penyediaan lapangan pekerjaan dan mengurangi kesenjangan tingkat kemiskinan. Berbagai kebijakan program dan kegiatan pemberdayaan umkm telah dijalankan. Pemerintah juga telah mengeluarkan Undang-Undang No. 20 Tahun 2008 Tentang Usaha Mikro, Kecil dan Menengah yang disahkan pada tanggal 4 juli 2008. Melalui UndangUndang tersebut menjadi gerbang bagi terbentuknya akses kredit umkm kepada lembaga perbankan serta diharapkan mampu mendorong umkm untuk mengembangkan unit usahanya sehingga meningkatkan produktivitas, mutu dan daya saing umkm itu sendiri.

Tujuan pemberian kredit kepada umkm sudah sesuai dengan pernyataan diatas dan juga tercantum dalam pasal 5 UU No. 20 Tahun 2008 Tentang Perbankan Syariah.

Akan tetapi praktek penerapan pemberian krdit di berbagai perbankan yang ada belumlah berjalan sesuai dengan sistem dan asas-asas hukum ekonomi syariah, dan juga tidak sesuai pada tujuan dalam UU Perbankan Syariah. Misalnya pemberian kredit di bank konvensional tidak disertai dengan pengawasan penggunaan pinjaman beda halnya di sistem perbankan syariah memakai sistem pengawasan langsung pengguna kredit harus sesuai dengan tujuan kredit yang benar-benar dipakai untuk dunia usaha.

\section{B. METODE PENELITIAN}

Metode yang digunakan dalam penelitian ini adalah metode kualitatif merupakan metode yang menekankan pada pemahaman mengenai masalah-masalah atas problematika sosial berdasarkan kondisi realitas (nyata) dan natural setting yang kompleks dan rinci, penelitian kualitatif berusaha mendapatkan pemahaman, pencerahan terhadap fenomena dan eksploitasi pada situasi yang sama. ${ }^{7}$ Adapun pendekatan yang digunakan adalah pendekatan yuridis normatif yaitu penelitian hukum yang dilakukan dengan cara meneliti bahan pustaka dengan cara mengadakan penelusuran terhadap permasalahan yang diteliti dan pendekatan sosial kultural. Adapun sumber data bersumber data primer yang diperoleh dari hasil wawancara langsung dan data sekunder

${ }^{6}$ Kasmir, Bank Dan Lembaga Keuangan Lainnya, (Jakarta:PT Raja Grafindo Persada,2005), h.140.

${ }^{7}$ Suharsimi Arikunto, Dasar-Dasar Research, (Bandung: Tarsito,1995), h.25. 
yang berupa informasi tertulis dari literatur. Pengumpulan data melalui metode observasi, wawancara, dokumentasi, dan tahap akhir adalah menarik kesimpulan.

\section{HASIL DAN PEMBAHASAN}

1. Praktek pemberian kredit kepada umkm

Adapun alur mekanisme pemberian kredit kepada umkm ialah sebagai berikut :

a. Tahap pertama yang dilakukan adalah tahap permohonan kredit, dimana pihak umkm mengajukan permohonan tertulis kepada pihak bank yang kemudian akan mengisi formulir.

b. Tahap kedua yaitu analisis kredit atau tahap pemeriksaan, dimana bank BRI Luyo Cabang Polewali punya cara sendiri dalam menganalisis kredit tetapi tidak bertolak belakang dengan pedoman Bank Indonesia, setelah syarat-syarat telah dilengkapi oleh pihak umkm selanjutnya pihak bank yang dalam hal ini Mantri akan melakukan peninjauan langsung ke lapangan untuk mengetahui apakah pihak umkm layak atau tidak mendapatkan pinjaman kredit. Pihak bank akan memberikan pertanyaan terkait dengan permohonan kredit :

1) Mencocokkan berkas-berkas pihak umkm sesuai dengan aslinya.

2) Menanyakan hal-hal yang berhubungan dengan usaha pihak umkm,seperti modal pinjaman tujuannya untuk mengetahui apakah pihak umkm mampu atau tidak mengembalikan pinjaman atau tidak.

c. Tahap ketiga yaitu pemberian pinjaman kredit, pada tahap ini pihak umkm akan mengetahui keputusan bank yang berisi persetujuan mendapatkan atau tidak pinjaman kredit sesuai permohonan yang diajukannya. Setiap pejabat yang terlibat dalam kebijakan persetujuan pemberian kredit harus dapat memastikan bahwa:

1) Setiap kredit yang diberikan telah sesuai dengan ketentuan perbankan san prinsip-prinsip pengkreditan yang sehat.

2) Dalam pelaksanaannya pemberian kredit telah sesuai dengan kebijaksanaan pengkreditan bank (KPB) dan pejabat pemutus kredit (PPK)

3) Keputusan persetujuan pemberian kredit oleh pejabat pemutus kredit telah didasarkan pada analisis kredit yang jujur, objektif, cermat, seksama dan harus independen.

4) Bank sudah yakin bahwa pemberian kredit sudah sesuai dengan rambu-rambu pedoman pengelolaan kredit dan dapat dilunasi oleh kreditur dan tidak akan menjadi kredit bermasalah.

5) Keputusan yang dibuat oleh para pejabat pemutus kredit sudah diputuskan secara profesional dan tidak dipengaruhi oleh pihak yang tidak bertanggung jawab. ${ }^{8}$

\footnotetext{
${ }^{8}$ Moh Tjoekam, Perkreditan Bisnis Inti Bank Komersial (Konsep Teknik dan Kasus), (Jakarta:PT Gramedia Pustaka Utama,1999),h.183.
}

Iqtishaduna: Jurnal Ilmiah Mahasiswa Jurusan Hukum Ekonomi Syariah 


\section{Ketentuan Hukum Ekonomi Syariah Terhadap Pemberian Kredit Kepada Umkm}

Ajaran Islam memuat secara jelas tentang bunga atau riba. Seseorang yang memakan riba sangat dikutuk dan diingatkan akan diancam dengan siksa neraka. Disebutkan bahwa riba merupakan perbuatan orang-orang yang tidak beriman, dan sebagai ujian bagi orangorang yang beriman untuk meninggalkannya. ${ }^{9}$ Dalam Islam, praktik pengkreditan tidak dilarang bahkan dianjurkan agar terjadi hubungan yang saling menguntungkan yang pada gilirannya berakibat pada hubungan persaudaraan. Dalam perbankan berdasarkan prinsip syariah sebenarnya penggunaan kata pinjam-meminjam kurang tepat digunakan karena dua hal. Yang pertama selain kata pinjaman masih banyak metode yang diajarkan oleh syariah selain pinjaman yaitu jual beli, sewa menyewa, bagi hasil. Kedua dalam Islam pinjam-meminjam adalah akad sosial bukan akad komersial yang artinya apabila seseorang meminjam sesuatu ia tidak boleh disyaratkan untuk memberikan tambahan atas pokok pinjamannya. Hal ini, didasari atas hadis Nabi saw. yang menyatakan bahwa setiap pinjaman yang menghasilkan manfaat adalah riba. Sedangkan para ulama sepakat bahwa riba itu haram, Jadi meminjam uang di bank konvensional yang terdapat bunga di dalamnya termasuk kredit merupakan hal yang dilarang karena bunga bank termasuk riba yang diharamkan.

Sekalipun ayat al-Qur'an dan hadits Nabi sudah sangat jelas melarang praktek riba, namun masih saja ada beberapa cendikia yang membenarkan praktik riba dengan alasan:

a. Dalam keadaan darurat, bunga halal hukumnya

b. Hanya bunga yang dilipat ganda saja yang diharamkan, sedangkan suku bunga yang wajar diperkenankan.

c. Bank sebagai lembaga tidak termasuk sebagai mualaf, sehingga bank tidak terkena khitab yang dilarang sebagaimana di dalam al-Qur'an dan hadits. ${ }^{10}$

Majelis fatwa sedunia juga memberikan kontribusi hukum terkait permasalahan riba dan bunga yang merambah dalam dunia perekonomian sekarang ini. OKI (Organisasi Konferensi Islam) memutuskan bahwa praktik perbankan dengan sistem bunga tidak sesuai dengan syariat Islam, maka diperlukan lembaga keuangan (bank) yang menjalankan operasinya sesuai dengan prinsip syariah. Keputusan inilah yang mendorong terbentuknya Islamic Development Bank (IDB). Mufti besar Mesir memutuskan bahwa bunga bank termasuk salah satu bentuk riba yang diharamkan. ${ }^{11}$

Ekonomi Islam didasarkan pada prinsip syariah tidak mengenal konsep bunga karena menurut Islam bunga adalah riba yang haram (terlarang) hukumnya. Artinya, bisnis dalam Islam yang didasarkan pada prinsip syariah tidak mengenal pembebanan bunga oleh pemilik modal atau investor atau kreditur atas penggunaan uang yang dipinjamkan oleh kreditur (pemilik modal) kepada debitur (peminjam uang). Konsep bunga adalah yang dipraktikan dalam bisnis berdasarkan kapitalisme, konsep bunga yang diterapkan kapitalisme tersebut tidak memperdulikan atau mempertimbangkan apakah bisnis debitur mendapatkan keuntungan atau mengalami kerugian. Baik bisnis debitur mendapatkan

\footnotetext{
${ }^{9}$ Sumar'in, Konsep Kelembagaan Bank Syariah. (Yogyakarta: Graha Ilmu, 2012),h.24.

${ }^{10}$ Antonio Syafii, Bank Syariah dari Teori ke Praktik, (Jakarta: Gema Insani Press, 2001), h.54.

${ }^{11}$ Sumar'in, Konsep Kelembagaan Bank Syariah. (Yogyakarta: Graha Ilmu, 2012), h.31.
} 
keuntungan atau mengalami kerugian, kreditur tetap saja menerima atau sebaliknya debitur membayar bunga. Dalam keadaan ekonomi makro mengalami krisis, baik secara nasional atau global, tetap tanpa ampun debitur berkewajiban membayar bunga kepada kreditur. Dengan kata lain, kapitalisme tidak berdiri di atas norma-norma etika, atau norma-norma tepo seliro atau toleransi, atau norma-norma kemanusiaan. ${ }^{12}$

Penetapan tingkat bunga yang rendah akan dirasakan sangat membantu dan menguntungkan bagi debitur hanya ketika bisnis debitur mengalami kemajuan. Namun ketika bisnis debitur mengalami kegagalan dan tidak lagi dapat menjadi sumber untuk menghasilkan uang bagi debitur untuk mencicil dan melunasi bunga pokok pinjamannya, maka bunga rendah tersebut berubah menjadi monster yang sangat menakutkan bagi debitur. Menjadi lebih mengerikan lagi bila dihitung secara berbunga-bunga (compounded), yaitu terhadap bunga yang tertunggak dibebankan lagi bunga. Bila hal itu terjadi maka setelah sekian lamanya sering jumlah keseluruhan bunga yang harus dilunasi oleh debitur dapat berjumlah lebih besar daripada pokoknya. ${ }^{13}$ Dalam syariah, imbalan dari modal tidak berbentuk bunga (interest) karena bunga dianggap riba yang hukumnya haram menurut syariah. Menurut syariah, modal harus dalam bentuk keuntungan (profit). Oleh karena itu, modal tidak boleh dipinjamkan kepada pihak lain kecuali dipinjamkan tanpa bunga. Modal dapat menghasilkan bukan dalam bentuk bunga melainkan dalam bentuk keuntungan dengan cara menggunakan modal tersebut untuk bertransaksi jual-beli. ${ }^{14}$

Tingkat suku bunga dalam bank syariah adalah nol, karena bank syariah menggenerate profit (keuntungan) tidak berdasarkan meminjamkan uang melainkan dari transaksi bisnis sektor riil.

Perjanjian kredit pada perbankan syariah harus didasarkan pada pengajuan permohonan kredit dan adanya prosedur dalam pemberian kredit serta adanya penilaian kredit, dimana dalam praktiknya didasarkan pada skin bagi hasil dengan besar margin tertentu. Pada dasarnya pelaksanaan perjanjian kredit pada perbankan berdasarkan prinsip syariah mengandung asas kemitraan dan asas kebebasan berkontrak yang didasarkan oleh kesepakatan bersama para pihak dalam pemberian kredit harus berdasarkan prinsip kehati-hatian.

Akan tetapi apabila mengacu pada keputusan Dewan Syariah Nasional Majelis Ulama Indonesia (MUI) pusat pinjam uang di bank konvensional termasuk riba karena ada bunga yang diterapkan. Tapi, keputusan ini dikecualikan untuk wilayah di pelosok Indonesia yakni wilayah yang belum terjangkau perbankan syariah, maka diperbolehkan menggunakan bank konvensional dalam konteks darurat.

\section{PENUTUP}

Berdasarkan data yang diperoleh di lapangan dan hasil pembahasan yang dilakukan maka dapat diambil kesimpulan sebagai berikut :

\footnotetext{
${ }^{12}$ Sutan Remy Sjahdeini, Perbankan Syariah: Produk-produk dan Aspek-Aspek Hukumnya, (Jakarta: Kencana Perenada Media Group), h. 157.

${ }^{13}$ Sumar'in, Konsep Kelembagaan Bank Syariah, h.157.

${ }^{14}$ Sumar'in. Konsep Kelembagaan Bank Syariah, h.158.
} 
1. Proses pemberian kredit usaha rakyat (KUR) dilakukan melalui beberapa tahap yaitu: tahap permohonan kredit, tahap peninjauan dan analisis kredit (tahap pemeriksaan), tahap pemberian putusan, serta tahap pencairan kredit/ akad kredit. Calon debitur mengajukan permohonan kredit usaha rakyat (KUR) secara tertulis beserta syarat-syarat lain yaitu fotokopi KK, fotokopi KTP serta surat keterangan usaha dari Kepala Desa kepada pihak BRI Unit Luyo Cabang Polewali . Setelah syarat-syarat dilengkapi, BRI Unit Luyo Cabang Polewali akan melakukan penelitian dan peninjauan langsung kepada calon debitur termasuk usaha calon debitur. Pihak bank akan memberikan putusan atas permohonan kredit yang diajukan oleh calon debitur. Setelah itu adalah tahap pencairan atau akad kredit, dalam tahap ini terdiri dari beberapa tahapan yaitu tahap persiapan pencairan, tahap penandatangan perjanjian pencairan, fiat bayar serta pembayaran pencairan kredit usaha rakyat. Berkas atau kelengkapan pencairan disini adalah surat pengakuan hutang, dengan ditandatanganinya surat pengakuan hutang oleh kedua belah pihak maka tahap-tahap dalam proses pelaksanaan pemberian kredit usaha rakyat telah selesai sehingga timbullah hak dan kewajiban bagi masing-masing pihak.

2. Mengenai mekanisme pemberian kredit kepada UMKM pada Bank BRI Luyo Cabang Polewali sudah sesuai dengan prosedur yang berlaku hanya saja jika dibenturkan dengan hukum Islam, maka pemberian kredit pada pada Bank BRI Luyo Cabang Polewali masih menjadi perdebatan, karena sebagian ada yang membolehkan dan sebagian ada yang tidak memperbolehkan. Dalam Islam Praktik perkreditan (pinjam-meminjam) tidak dilarang, bahkan dianjurkan agar terjadi hubungan saling menguntungkan yang pada gilirannya berakibat pada hubungan persaudaraan. Dalam perbankan berdasarkan prinsip Syariah, sebenarnya penggunaan kata pinjam-meminjam kurang tepat digunakan disebabkan dua hal. Pertama, pinjaman merupakan salah satu metode hubungan finansial dalam Islam. Masih banyak metode yang diajarkan oleh Syariah selain pinjaman, seperti jual beli, bagi hasil, dan sewa. Kedua, dalam Islam pinjam meminjam adalah akad sosial bukan akad komersial, artinya bila seseorang meminjam sesuatu ia tidak boleh disyaratkan untuk memberikan tambahan atas pokok pinjamannya. Hal ini didasari atas hadis Nabi saw. yang menyatakan bahwa setiap pinjaman yang menghasilkan manfaat adalah riba. Sedangkan para ulama sepakat bahwa riba itu haram karena itu, dalam perbankan berdasarkan prinsip syariah tidak disebut kredit tapi pembiayaan (financing). 


\section{DAFTAR PUSTAKA}

\section{Buku}

Arikunto Suharsimi, Dasar-Dasar Research, Bandung: Tarsito, 1995.

Kasmir. Bank dan Lembaga Keuangan Lainnya. Jakarta: PT. Raja Grafindo Persada. 2005.

Sjahdeini Sutan Remy Perbankan Syariah: Produk-produk dan Aspek-Aspek Hukumnya. Jakarta: Kencana Prenada Media Group, 2018.

Suhendi Hendi. Fikih Muamalah. Jakarta: Rajawali Pers, 2002.

Sumar'in. Konsep Kelembagaan Bank Syariah. Yogyakarta: Graha Ilmu, 2012.

Syafii Antonio. Bank Syariah dari Teori ke Praktek. Jakarta: Gema Insani Press, 2001.

Tjoekam Moh. Perkreditan Bisnis Inti Bank Komersial. Konsep Teknik dan Kasus. Jakarta: PT Gramedia Pustaka Utama, 1999.

\section{Jurnal}

Ilyas Musyifikah dan Bahar Sahruni "Tinjauan Hukum Islam Terhadap Sistem Mappakatenni Galung Di Kel. Lalebata Kec. Panca Rijang Kab. Sidrap”, Jurnal Ilmiah Mahasiswa Hukum Keluarga Islam, 2 no. 1. 2020.

Maloko Thahir dan Aulia Abshir Rahmi, "Tinjauan Hukum Islam Terhadap Pengupahan Jasa Kerja Skripsi Secara Online”, Jurnal el-Iqtishady, 3 no. 1, 2021.

Mulia Muhammad Mahmudah, "Membentuk Sumber Daya Manusia Perbankan Syariah Melalui Manajemen Hati", el-Iqtishady 1, No.2, Desember 2019.

Sinilele Ashardan Aathifah Nursaidi Naurah "Perlindungan Hukum Nasabah Dalam Transaksi Pinjaman Online (Fintech)", Jurnal el- Iqtishady, 3 no. 1, 2021. 